\title{
"TRUSTS" AND "LIVING LAW" IN EUROPE
}

Jaro Mayda $\dagger$

I

The general trust doctrine and practice which is a universal common-law device for handling private affairs of individuals is unknown to European laws. ${ }^{1}$ Continental and Latin-American comparatists have reacted to it according to their temperament, erudition, analytical abilities, isolationist inclinations, or sentimental preferences. The variety of their opinions is, in fact, quite commensurate with the kaleidoscopic nature of the institution itself: ". . . we deem it dangerous to incorporate . . . in our law an exotic institution like the AngloAmerican trust," says a somewhat conservative Spanish gentleman; ${ }^{1 *}$ “. . . trust law piles up outmoded conceptions which have become useless and foolish fictions, at which nobody will be more marvelling than the English themselves once they have them abolished," foretells a Dutch professor who emphasizes his general veneration for the English law ${ }^{2}$ ". . . . the trust concept and trust practice do not fit into the continental legal systems. We are not faced with a minor incongruity between civil and common law, but with a basic contrariety as to their legal approach," is the opinion of a keen German student of both systems ; ${ }^{3}$ trust is a "cuckoo in the civil-law nest"-one of the famous "last words" of Sir Maurice Amos 4-is a middle-of-the-road opinion which assumes the existence of trusts in European law but considers them "out of line."

On the "progressive" side of the ledger, we find the wishful voices of those who have been impressed with the flexibility of the commonlaw trusts, and have made various exploratory expeditions through the

$\dagger$ Assistant Professor of Law, University of Wisconsin Law School. This paper was originally prepared and delivered as an address.

1. The English word "trust" in the corporate and monopolistic sense is currently used on the Continent.

1. Garrigues, Law of Trusts, 2 AM. J. Comp. L. 25, 35 (1953).

2. Meijers, De Trustee in het Burgerlijk Recht, WeEkblad voor PrIvatrecht, Notaris-AMBT aNd Regrstratie 413 (1927), quoted by Nussbaum, Sociological and Comparative Aspects of the Trust, 38 CoL. L. REv. 408, 428-29 (1938).

3. Id. at 428. I owe to Professor Nussbaum also the descriptive term, "kaleidoscopic," used above.

4. Amos, The Common Law and the Civil Law in the British Commonwealth of Nations, 50 HARv. L. REv. 1249, 1264 (1937). My attention to this expression was drawn through Lepaulle, Book Review, 4 Rev. INT. DE Drorr COMr. 337 (France 1952). 
letter and practice of European and Latin-American laws in order to prove that trusts actually parade in civil-law systems under various misleading labels. ${ }^{-}$The usual conclusion has been that the earlier these trust practices are recognized for what they actually are and fully developed, the better off the "civilians" will be. ${ }^{6}$ Such enthusiastic voices have often outrun reality and were criticized for it. ${ }^{7}$ An even more important point: they almost invariably put the legal cart before the socio-economic horse. ${ }^{8}$

The general consensus of almost all writers seems to be that the main-if not the only-reason why the common-law trust doctrine has not taken root in the civil-law countries is the basic concept of indivisible property rights which precludes the application of the very essence of the common-law trusts, i.e., the idea that to the same res may be attached legal rights entertained by one person and equitable rights held by someone else. The rather uniform immunity of civil law to the idea of enforceable equitable ownership has been interpreted from several backgrounds, the most often cited being (1) the legalhistorical, (2) the ideological, (3) the conceptual, and (4) the technical.

The legal-historical explanation, based on the Roman-law tradition in the civil law, is so patently belied by facts that it belongs in the sphere of fiction rather than legal scholarship. The ideological explanation points to the violent revolutionary break with feudalism on the Continent; thus the very legal structure from which English trusts grew was discarded in favor of a concept of property expressing the emancipation of the individual and giving him basically a full sovereignty of ownership. The conceptual explanation emphasizes the clarity and systematic character of civil-law thinking, distinguished from the pragmatic empiricism of Anglo-Saxon jurisprudence. Although theoretically correct, this stereotype draws a non-existing line between law and life, and is therefore of little practical value. Finally, the technical explanation points to the principle of publicity in civillaw systems, which requires public registration of all transactions creating rights in rem for enforceability, and the limited repertory of rights

5. Huber, Trust and "Treuhand" in Szenss Law, 1 INT'L \& CoMp. L.Q. 64 (1952); Patton, Future of Trust Legislation in Latin America, 20 TULANE L. REv. 542 (1946) ; Bolgár, Why No Trusts in the Civil Law, 2 Am. J. Comp. L. 204, 216-17 (1953).

6. Lepaulle, Traite theorique er pratiQue des Trusts (1932); Lepaulle, Civil Law Substitutes for Trusts, 36 YALE L.J. 1126 (1927). 62,63

7. Cf., e.g., Nussbaum, supra note 2 , at 419 , and reviews cited therein in notes

8. See note 11 and text following note 51 infra.

9. Treated excellently and with copious references by Miss Bolgár, supra note 5 , at 204-08. 
in rem, which are strictly defined in the codes and do not contain the in rem right of the trust beneficiary.

Of the explanations which cannot be dismissed a limine as the legal-historical one, the technical explanation is most open to criticism because of its mechanistic-legalistic character. It ignores this simple principle: if a legal system of a country, where the coordination and control of interests develops without the interference of an authoritarian ordering principle, contains a norm or legalizes a practice, it means that the community pattern requires it. The same norm or practice will be most likely omitted where there is no need for it, or where the interests involved can be taken care of in a subsidiary way, or where it is considered against public policy. Law is a function of a free society, not its straitjacket. Consequently, the roster of the rights in rem in the civil codes would be expanded if legal practice required it. $^{10}$

Nor are the four standard explanations, individually or collectively, capable of explaining the situation satisfactorily. Rather, I would like to assume that (1) civil laws have developed certain trustlike practices as far as the individual interests and peculiarities of each country have required it, and (2) the factors governing or limiting this process were not primarily legal, jurisprudential-ideological, or historical in the formal sense, but functional, dynamic and pragmatic -social and societal, cultural (in the anthropological sense) and, above all, economic. ${ }^{11}$

\section{II}

This article will attempt only to illustrate some roots of these assumptions. Chosen as a frame of reference for this discussion is the French fondation-an institution which is about as close as civil law comes to one type of trust, namely the charitable trust. It should be emphasized at this point that the concentration of my discussion on a

10. Batiffol, The Trust Problem as Seen by a French Lazeyer, 33 J. Comp. LEG. \& INT'I L. (3d ser.) pt. 3, at 18, 25 (1951). Professor Batiffol implies this thought, although the rest of his article-originally a report to the Anglo-French Legal Conference in 1949-which contains interesting information and insights, nevertheless follows in essentials the traditional line.

11. E.g., Nussbaum, supra note 2, at 413 , seems to represent well the historicaltraditional over functional emphasis although he makes correct allusion here and elsewhere to the economic ingredients in the modern development of trust, especially in the United States. Bolgár, supra note 5, at 214, suggests correctly the human-social substance of the normative process, but then proceeds to represent the various trustlike legal institutes in European legal systems negatively as obstacles to the reception of trust rather than positively as evidence of the degree to which the normative process has created trust-with quotation marks or without-on the Continent. She also misses the economic dimension of the problem, suggesting only a jurisdictional and ideological explanation, both of a formalistic character. Id. at 217-18. It must be stressed otherwise that I am fully aware of the degree of statistical evidence, in addition to a much more detailed legal and sociological analysis, that would be necessary to support the "economic thesis." It seems, however, at least as profitable to take this angle as to perpetuate the overworked stereotypes. 
single trust-like practice in a single country does not mean that there are not other quasi-trusts in various civil-law systems, especially in the sphere of inheritance and commercial laws. Rather, the problem and the country have been selected for a variety of reasons of which at least four deserve mention: (1) French law has, by its doctrine and/or positive rules, influenced the majority of the civil-law world; (2) by its conceptual and ideological character, French law is probably the most conservative Continental system and is, therefore, likely to lend much support to the formal explanations of the absence of fullfledged trusts in the civil-law systems; (3) the development of French foundations is an excellent example of the growth of customary law -or, if you wish, "common law"-in a Continental country; ${ }^{12}$ (4) an important ingredient of the process in France was the well-known cy près doctrine, which, as applied in this connection, may make even a most liberal equity judge stop and wonder.

As far as the French Code Civil is concerned, there is to date no such thing as a foundation. ${ }^{13}$ The encyclopedic survey of the first half-century of French post-Revolution law speaks about foundations in the past tense and states that "they have played a fairly important role under the feudal system." 14 Thus, by the middle of the nineteenth century, foundations not only were not recognized by the codified law, but also were officially written off as a fact of life. The reasons for discarding the institution in the Napoleonic Code were mainly the fear of mortmain ${ }^{15}$ and the incompatibility with the republican ideology of property rights-absolute, exclusive, unitary-which excluded $a$ priori the idea of a limited, "naked" ownership right of the trustee vis-à-vis the actual, economic rights of the cestui. This division, we read clearly, was "constitutive of the feudal system," 16 and therefore ideologically and politically unacceptable to the drafters of the Code. ${ }^{17}$

12. Professor Savatier's remarks on this point, "this shows in a startling way that statutory text does not make the law, but that the development of needs and social ideas is much more important than the written rules," illustrates interestingly the necessity of emphasizing the role of the "living law" in France 25 years ago. Savatier, [1928] Dalloz Jurisprudence [hereinafter D.] II. 122.

13. Savatier, comment on the cases De Renesse v. Robineau, and Epoux DevilliersAlexandre $e t$ al. v. Epoux Gustave Alexandre et al., [1928] D. II. 121, calls the silence of the Code Civil "most complete and sorry." The lucid and comprehensive summary of Professor Savatier has been generously drawn upon as background for the following discussion. See also O'Neal, The Universality of a Curse: "Future Interests" in the French Law, 3 LA. L. REv. 795 (1941), with general background, copious references and a concise summary of fondation. Id. at 811-13.

14. 5 Jur. Gen., Vo Fondation. Such a bequest (liberalité) is defined there as "in favor of a public establishment or even a dedication of a sum for a religious function or service." (Italics added.)

15. Compare the instructive survey with references in RAEINSTEIN, CASES ON DECEDENTS' EsTATES 399 (1947).

16. 5 Jur. Gesı, Vo Propriété Féodale, No 254.

17. The psychological aversion and ridicule was expressed clearly more than 100 years later: ". . foundations in the proper sense, used ... especially in 
Besides the lack of legitimation by the Code, there were other factors which checked the development of foundations. Four of them appear controlling.

Under the still valid system of legitime, the testator has been obligated to leave a certain portion of the estate (réserve) to his heirs by law. Because of the hotchpot rule, ${ }^{18}$ légitime operated inter vivos as well as mortis causa. Only the remaining portion-not more than one-half of the estate ${ }^{19}$ —could be bequeathed. This economic limitation was intensified by the element of public control. Donations with the view of establishing a foundation could be made only in favor of institutions and purposes approved by the government, and they required public authorization. ${ }^{20}$ The whole situation was further complicated by legislation and practice which established the local departments of welfare as the legal representatives of the poor of the community. ${ }^{21}$

The third factor checking the development of foundations was the statutory requirement of continuity of ownership. Accepting the Roman rule, the Napoleonic Code stipulated that to be eligible the heir must have been at least conceived at the time of the testator's death. $^{22}$ In want of a specific provision concerning the legal per-

England and in Germany ... respond marvellously to the sentiment of vanity under the impulse of which the founder usually acts, since he sees in the foundation means to perpetualize his name." 3 BAudRY-LACANTINerIe, Précis DE DroIT CIVIL $\$ 870$ (10th ed. 1910).

18. Code Crvir arts. 829,843 et seq.

19. Id. art. 913.

20. Id. art. 910, which, Dean Baudry-Lacantinerie remarked rather parenthetically, "has produced interesting developments in application to foundations." 3 BAUDRY-LACANTINERIE, op. cit. supra note 17. The French conception was based on the "basic principle" according to which corporate legal personality (personalité civile) can be acquired only through the intervention of public authority, usually in the form of declaring that the object seeking independent legal status is of public utility. Ibid.

See also, Law of July 1, 1901, arts. 2, 17, [1907] ButLETrN DEs Lors (12th ser.) pt. I, at 307 (France) : unauthorized society is not capable of acquiring property $\dot{a}$ titre gratuit (without counter-performance). In criticizing the obstacles which the law and governmental practice have put in the way of foundations, Professor Planiol made almost half a century ago a point very pertinent to the topical issue of individual freedom versus statism: "One feels here the constant tendency of the government which tries to deny the individuals the faculty to act in public interest without using the governmental machinery or in competition with it." 3 Planiol, Traité Élémentaire de droit crvil \$3346 n.1 (5th ed. 1910-12). Compare state statutes requiring registration of charitable trusts with the Attorney General (N.H.) and reports by trustees to the Department of Public Welfare (Mass.). The attention to these practices has been drawn through Scott, Trusts in the United States, 31 J. CoMp. LEg. \& INT'L L. (3d ser.) 11, 17 (1949). Professor Scott also mentions the well known fact of systematic supervision of charitable trusts in England. Cf. Logan, Reports of Committees, 16 Mod. L. REv. 343 (1953).

21. Cf. 3 Planiol, op. cit. supra note $20, \S \S 3002,3336$ n.3. A clause in a testament or donation instrument which excluded the intervention of such a bureau in favor of the beneficiaries, was repeatedly declared by the courts as against public policy.

22. CODE CIVIL art. 906. 
sonality of foundations, this rule was applied by análogy. Consequently, a new foundation could not be created directly by a testament because it did not exist as a definite addressee of the bequest at the time of the testator's death or even the time of the execution of the will. ${ }^{23}$ There was no solution for this dilemma within the Code framework because of the fourth factor working against foundations-the lack of any statutory right or remedy in favor of the beneficiary against a legatee who received a bequest with the charge of establishing or endowing a charitable institution and ignored the charge.

The importance of this fourth factor can be illustrated by a case which also shows the role of the public welfare department. A donation was made to a charitable religious congregation with the charge of providing clothes for specified categories of the poor of the city of Lille. The local public welfare department, which intervened as the legal representative $e x$ officio of the poor, made claims beyond the actual terms of the bequest. The court rightly rejected them-and the case is uninteresting up to this point. But in a dictum, the appellate court defined the status of the beneficiaries, the poor, as that of creditors. ${ }^{24}$ The court arrived at this construction by applying the principles of stipulation in favor of third persons (stipulation pour autrui). Such a construction was possible because the beneficiaries-creditors were sufficiently defined in advance.

This was a remarkable step forward. Jurisprudence, the French case law, provided a remedy which the Code failed to offer. Equipped with such a remedy, the beneficiaries had all the essential predicates of an equitable ownership right. But the "precedent" did not have the practical significance of which it was susceptible. Nor is too much of a trust element to be read into the court's conception. Planiol makes it amply clear that the testator continued to have a free choice of ascribing or not ascribing to the "cestuis" the quality of creditors. ${ }^{25}$ Where the testator did not want to impose on the legatee anything but an honorable obligation, ${ }^{26}$ neither the beneficiaries nor even the heirs

23. Compare criticism in 1 ARMInJon-Nolde-WolfF, Traite de dRoIT comparé $\$ 363$ (1950): whereas, it is uncertain whether a child shall live when born, the foundation will come to life unless prevented to acquire the bequest. Belgium, Holland, Italy, Poland, Argentina, Germany, the Scandinavian countries, and the Soviet Union are among those which have introduced the right to constitute foundations directly. Id. $\$ \S 226,227,233,236,497,626,721,917$. Because the communist economic system is not a favorable medium, the institution of foundations has not taken root in Soviet Russia.

24. Douai, April 22, 1890, [1891] D. III 220. Planiol refers to this as a "rule," a term which will surprise many Anglo-American readers, especially if found in a civil-law text over 50 years old.

25. 3 Planiol, op. cit. supra note 20 , at 865 .

26. Cf. Cour de cassation (Req.), Jan. 7, 1902 [1903] D. I. 302, using the phrase "[legatee] burdened with a charge which is instituted only in [his] conscience and honor, and the realization of which is left to his discretion." 
at law had any action for the non-execution of the "trust." 27 This, Planiol opines, was one of the main reasons why the legal cue of the Lille case could not be fully picked up and developed.

The Lille case developed from a donation made in 1866. The important progress in the conception of foundations which this case marked can be visualized only against the backdrop of the preceding times. In the first half of the nineteenth century the anti-foundation ideology of the Civil Code fully prevailed and was supported by the courts. The typical case of that period seems to involve a bequest to a church for religious or welfare purposes. But about 1850 the French popular mind emancipated itself sufficiently from the revolutionary prejudice against the "dead hand." Personal interests started to go against, and later around, the straitjacket which had been imposed on them in the name of liberty. Yet charitable donations inter vivos not properly publicly sanctioned, and bequests made to foundations not already in existence, continued to be annulled by the courts without discussion. ${ }^{28}$

The official temper of the times can be inferred from an 1847 case which reached the Court of Cassation. ${ }^{29}$ A lower court, facing a discrepancy between the wording of the testament and a codicil, construed the testament so as to frustrate the creation of a foundation. The Court of Cassation upheld the exclusive right of the trial court to interpret the testament without the slightest concern for the fate of the foundation. A commentary which follows the citation of the case in Dalloz elaborates on the scope of this interpretation monopoly of the Courts of First Instance and singles out especially the right to decide whether a bequest was made to an intermediary ("trustee") and, if so, to annul it. According to the Civil Code, ${ }^{30}$ such dispositions are null and void in a case of a fraudulent agreement between the settlor and the "trustee," or when the settlor intended to bequeath through the "trustee" to a person legally incapable to benefit (for example, a physician who cared for the settlor during the malady which caused his death, or a legal person who or which did not exist prior to the

27. Especially in cases of universal legacies, where the beneficiaries of the foundation ( $s$ ) to be created were not defined ahead in terms of the Douai decision of the Lille case, note 24 stipra, there was only an action against the legatee for non-execution of the charges (l'action en révocation pour inexécution des charges). This action was given exclusively to heirs at law, not to the beneficiaries, since they were not known (at least as a defined class or group) and given status by the testator. Cf. 3 Planiol, op cit. supra note 20.

28. Savatier, supra note 13.

29. Cour de cassation (Req.), Nov. 15, 1847, [1847] D. IV. 166. The Cour de cassation is concerned only with reviews limited to questions of law and procedure, and has considered interpretation of testament to be a question of fact. 3 PLANIoL, $o p$. cit. supra note 20 , at 752 .

30. Cf. CODE CrviL arts. 896, 909, 911. 
death of the de cujus). But the annulment practice of the lower courts apparently did not require any proof of bad faith and affected even cases where the legatee was unaware that he was a mere "trustee."

A solution to the statutory obstacle to foundations was actually sought shortly after the Code came into force, and it was done in a manner reminiscent of the equitable remedies developed to mellow the formalistic excess of common law. In a precedential case, Conseil d'Etat, the French Supreme Administrative Court, granted ex post facto legal personality to a direct testamentary endowment, and followed this practice when requests for such legalization, mitigating the harsh statutory analogy of preexistence, began to reach the Conseil in larger numbers beginning with the middle of last century. ${ }^{31}$ But these efforts were in vain largely because of the attitude of the courts and the prevailing ideology of strict subordination of the law finding to the law making. As a result, foundations, whose endowment was denied because they were to come into being only on the basis of such an endowment, were given legal personality by administrative procedure making them eligible to accept and claim the bequest. But when they brought suits before regular courts against the estates in order to supplement their formal existence by economic substance, they invariably failed.

The hardship which such a jurisprudence generated was obvious, and it produced a remedy within the realm of the judiciary itself. The Court of Cassation refused the "good offices" of its administrative counterpart and continued to condemn direct foundations. It, however, began consistently to validate foundations established in a more subtle and devious manner. If a settlor appointed a capable legatee with a duty to establish a foundation (charge à fonder), he satisfied the requirement of continuity of ownership ${ }^{32}$ since the legatee was an existing person at the time of incumbency. But the court began to construe the legatee's right to the bequest as essentially that of a trustee. Consequently, action against him for nonperformance of the trust in favor of a foundation was honored even in a case where the charge consumed the whole legacy with the result that the legatee acted merely as a formal dépositaire of the bequests in favor of the real owner, the foundation. $^{33}$

31. Savatier, supra note 13 , at 122.

32. See text at note 22 supra.

33. Cf. 3 Planiol, op. cit. supra note 20, at 867-69. Planiol also makes the distinction beteween acquisition $\dot{a}$ titre onereux, a donation or bequest of an object which remains in the hands of the donee or legatee but the countervalue of which is to be paid to a third person, and the situation above where the beneficiary is the real donee or legatee, whereas the "apparent donee or legatee is only an agent of transfer (agent de transmission), a sort of a mandataire (agent of a principal) without profit or risk." Id. at 750 . Still elsewhere, he uses the term propriétaire fictif as distinguished from the real owner. Id. at 870 . 
One may well agree that this is a formalistic solution which possibly appears repugnant to the pragmatic Anglo-Saxon legal mind. It has been criticized in similar terms by French jurists as "artificial casuistry . . . shocking to those who try to disengage themselves from the slavery of words." 34 But artificial or not, the solution shows the capability of the system to overcome the slavery of the rigid statute and to find viable solutions for current interests even outside and against the written law. The whole picture acquires even more depth if it is considered in conjunction with the $c y$ près practice of French courts which has been inseparably linked with the jurisprudence in the matter of foundations.

The French cy près doctrine is based on the absolute right of the lower courts to interpret testaments. We have already seen how formalistically and arbitrarily a court availed itself of this right. ${ }^{35}$ Since then, the French practice has undergone a decline of such formalism, which Dean Pound graphically described as a "judicial slot machine," coining the term, however, at a time when the slot machine was already in the advanced stages of a dismantling process. Professor Savatier refers to the deformalization of French law-finding as an "increasingly marked aspiration of French courts to deliver in equity." 36

The earlier cases of $c y$ près construction ${ }^{37}$ were merely animated by the desire of the courts either to uphold the interpretation of the foundations themselves in cases where it was impossible to fulfill the original conditions of the bequests, ${ }^{38}$ or to protect the foundations from competing claims. In a 1923 case, ${ }^{39}$ the testatrix bequeathed the whole estate to a legatee with the substitutive condition that, if at his death his son did not have issue, the bequest should go to a charity. The legatee, however, predeceased the testatrix, and a distant relative,

34. The famous Academie Goncourt was the result of such "juristic verbal magicianship." It was merely necessary to rechristen (débaptiser) the testamentary executors as legatees, without changing anything in their mission, to make it legally obligatory. Savatier, supra note 13, at 122. Cf. 3 Planiol, op. cit. supra note 20, at 868 and references therein.

35. See text at note 29 supra.

36. Savatier, supra note 13 , at 122 . This seems to redeem at least partially Planiol's sigh a quarter of a century earlier-probably just about the time Pound started to crystallize his opinion about civil law-that "we believe we are progressing but often are less advanced than Roman law was, with the mitigating powers of the praetor." PLANIOL, op. cit. supra note 20, at 867 n.2.

37. Cf. also Cone Crvm art. 1157, according to which clauses in contracts which are susceptible of two interpretations should be construed so as to produce the desired effect rather than to frustrate it. This rule has been considered from the beginning as applicable also to testaments. 5 Jur. Gen., Vo Dispositions entre vifs et testamentaires, No 3051; Savatier, supra note 13, at 123 .

38. 5 Jur. Gen., Vo Culte, No 509; Cour de cassation (Req.), Nov. 4, 1895, [1896] D. I. 206.

39. Cour de cassation (Req.), Feb. 7, 1923, [1923] D. I. 239. 
beyond the reach of the réserve légale, attacked the acquisition of the bequest by the designated charitable foundation. But by then the policy was crystallized firmly in favor of foundations. In order to realize the goal, the court interpreted the testament so as to eliminate the voiding construction of a fideicommisary substitution (i.e., a double successive disposition in favor of two persons) which would have frustrated the charitable bequest. Rather, the testament was construed as actually containing two conditional legacies, one with a resolutory condition (in favor of the legatee), the other with a suspensive condition (in favor of the charity) contingent on the existence of a living grandchild at the time of the legatee's death. Since this contingency could not arise-the legatee was dead before the testament became executable-the court ruled that it was to be interpreted in the frame of reference in existence at the time of the testatrix's death. Consequently, the resolutory condition in favor of the legatee was to be considered nonwritten, leaving in force only that part of the testament which contained the suspended bequest in favor of the foundation.

The cy près doctrine came to a full blossom in two causes célèbres decided in 1926 and 1927 respectively. ${ }^{40}$ These cases consummated the long process toward the construction of foundations as quasi-trusts and their protection by judicial means in the absence of a statutory remedy. In both cases the courts faced not merely the task of giving remedy to a foundation against a nonperforming legatee, or of judicially legalizing the necessity of subsequent adjustments in the form or substance of a foundation and interpreting the bequest in a manner favorable to the realization of the charitable or cultural purpose. Here, the wills were defective in that they lacked capable legatees through whom the contemplated foundations could come into being. The task which the courts took upon them went one important step beyond the previous pattern of giving action against a non-performing but properly entrusted legatee.

In the first case, De Renesse $v$. Robineau, a bequest was made in favor of widows and orphans of the employees of the Banque de France and, as a substitute, Crédit Lyonnais. The testament was made in Spain and failed to follow the tested French pattern of the legatee serving as a "transmission belt" from the testator to the foundation-to-be. Under the strict application of the Code, the bequest should have been declared invalid. But the court found its way around the letter of the statute. It held that, it was true, the foundation did not exist at the time the will came in force, but the beneficiaries-the widows and orphans-existed. It was they the testatrix really wanted

40. See cases cited note 13 supra. 
to endow. The establishment of the foundation was, therefore, not the purpose but only the necessary form, a medium through which the main purpose could be realized. The task of making it possible was properly imposed on her estate as a charge of which the legal heirs must acquit themselves, acting as testamentary executors ex officio. Thus a foundation came into being without the intervention of a specific legatee with a charge $a$ fonder and the bequest from which it was endowed was considered, for all practical purposes, as held by the heirs in trust.

In the second case, Epoux Devilliers-Alexandre v. Epoux Gustave Alexandre, the establishment of a foundation seemed to be frustrated for two reasons. First, the testatrix specified that the foundation should be established in the form of a societé civile, ${ }^{41}$ the character of which was not suited for the pursuit of the charitable purpose; ${ }^{42}$ second, the three legatees supposed to create this corporation renounced. ${ }^{43}$ The appellate court virtually "went to work" on the will. It used a statutory provision concerning the nullity of impossible conditions in dispositions inter vivos or mortis causa and cancelled the provision of the will concerning the corporation which was the first obstacle to the realization of the foundation. But there still remained the problem of the execution of the bequest. The renunciation by the three legatees made the estate lapse, falling back on the legal heirs by virtue of the succession rules of the Code. But the court was determined that the will should "produce its full and entire effect." Therefore, it simply directed the heirs by law to execute the charge of the original legatees in favor of the charitable purpose.

41. Distinguished from a société commerciale, the purpose of which is either 2 specific enterprise, or the carrying on of a trade or profession. CoDE Crvil art. 1841 2 Planiol, op cit. supra note 20 , at 628 .

42. The question whether a corporation having essentially a profit purpose (but lucratif) can be the proper outer shell for a foundation has been disputed. E.g., compare 2 PLANIoL, op. cit. supra note 20 , at 629,$642 ; 3$ id. at $866 \mathrm{n} .1,869 \mathrm{n} .1$, with Lévy-Ullmann \& Grunebaum-Ballin, Essai sur les fondations par testament, 3 REVUE TRIMESTRIELLE DE DROIT CIVIL 253 (France 1904). See also 1 ARMINJONNOLDE-WOLFF, op. cit. supra note 23 , at $\$ 362$ which, however, does not cite the 1914 case below. The disapproving opinion, repeatedly criticized by Planiol, seems to have prevailed in the jurisprudence. Cour de cassation, March 11, 1914, [1914] D. I. 257 , cited by Savatier, supra note 13. The degree of difference of opinion on the question is evidenced by this decision in pleno (toutes chambres réunies) of the Court of Cassation, by which it establishes a "precedent" binding on the lower court to which is the case remanded.

43. The situation was still further complicated. According to the will, the "trust corporation" to be created, was to possess all of the testatrix's real property and use three quarters of the yearly rent proceeds to endow charitable work for the war blind and orphans of war (the testament was made in 1917). The societé was to last "at least 50 years." The plaintiffs objected that this was in violation of CODE Crvil art. 1026 which states that testamentary executors may be given seisin of all or a part of the testator's real property (immobiliers) but only for the period of one year and one day. The court construed the positions of the legatees as testamentary executors, but held that since the provision of the testament violated Article 1026, it was to be considered not written according to CODE CIVIL 
Because of a fine point of distinction between the two decisions, the second decision was criticized as going overboard and undermining the quasi-trust fiction developed by the previous jurisprudence. ${ }^{44}$ But what stands out is the common denominator of these two cases which culminate a long evolution: the ability of a reputedly rigid statutory system to display a functional vitality and pragmatic flexibility usually ascribed only to common law.

\section{III}

Returning now to the original thesis outlined at the outset of this article, the foregoing discussion has illuminated directly or by implication the first point, namely the creative function of the "living law" in the development of trust practice illustrated by a specific case study. However, this was done without supporting in any way the second assumption, that the factors controlling this process are functional, dynamic, pragmatic, and primarily economic. A broader comparative base is necessary for that purpose.

A quick survey of what one may call the "ecology of trusts" shows some interesting facts. We find, for instance, that Lichtenstein introduced trusts in 1928; that Switzerland and Germany are generally closer to the trust conception in their commercial practice than France; that Mexico and Panama received trusts in one form or another although they are not closer culturally or historically to the United States than Belgium or Holland are to England; that Quebec and Louisiana were without trusts for a long time although subject to controlling common-law jurisdictions.

When looking for the "whys" in such situations, we are struck by the presence of a common economic element. Lichtenstein did not find its civil-law system a serious obstacle to trusts because its aim was to attract foreign capital to operate in and through the country; ${ }^{45}$ Switzerland's and Germany's economic and commercial life appears on the whole more dynamic than France's; ${ }^{46}$ the degree of politico-

art. 900 ("Whenever property is disposed inter vivos or by a will, the conditions , which are impossible or contrary to law or good morals shall be considered as un'written." [P. 260, Cachard transl. 1930.] This construction did not favor the plaintiffs but rather the testamentary intention, i.e., the endowment.

44. Savatier criticizes it because in the interpretation of the court the charge loses its personal character and becomes merely a burden on the estate. Thus "one falls back into the nullity of bequests to non-existing persons." Savatier, supra note 13 , at 124 .

45. Lichtenstein has been dubbed "European Delaware" 2 ARMInjon-NoldeWoLFF, op. cit. supra note 23 , at 220 .

46. On the other hand, the statutory provisions of Code Napoléon against "dead hand" and trusts were made in favor of, and resulted in, a considerable increase of real property mobility, and thus, also an increased economic productivity of land. Cf. Rheinstein, op. cit. supra note 15 , at 400 . 
economic ties of Mexico and Panama to the United States is much higher than it has been in the case of Belgium and Holland to England; Louisiana and Quebec were getting along with usufruct, ${ }^{47}$ fideicommis, ${ }^{48}$ mandate, agency, and the various testamentary practices which can serve as substitutes, for trusts, until they were increasingly taken into the rapidly expanding economies of their countries. ${ }^{49}$

A learned and sophisticated recent French treatise suggests that "the French jurist cannot visit the universities, hospitals and other general social institutions [in Great Britain and the United States] prospering because of the [trust] mechanism without the comparison with his own country and a feeling of envy." ฐ0 One may be allowed to ask whether it is really the legal technique of trusts or rather the greater availability of money-in the broadest economic-fiscal sense -which makes the difference. It should not be forgotten that the trust conception made its first inroad in Louisiana when Paul Tulane contemplated the donation, realized in 1882 , which built Tulane University.

In a similar vein, suggestions that the introduction of trust practice may be the needed life shot to French economy sound somewhat unrealistic. $^{51}$ If this proposition were true, a revamping of the respective sections of the French Code and the import of the Anglo-American "trust family" would have been the right thing to do after the Second World War-not the short-range help under the European Recovery Program. Yet this is obviously not so. Besides, the idea of divisible property rights, suggested as a sufficient basis for trusts, ${ }^{52}$ is not absent in French and other Continental laws, as innumerable Code citations could prove. ${ }^{53}$ This being so, it would require relatively simple legis-

47. For a summary dicussion, see O'Neal, supra note 13, at 808 et seq.

48. Id. at 797 et seq. Fideicommis was excluded in the original Lousiana Code, which went thus beyond the Code Napoléon. Stone, Trusts in Louisiana, 1 INT'L \& CoMP. L.Q. 369 (1952).

49. I am aware of the fact that this generalization may be too simplified and that its verification would require extensive empirical study and documentation. It is presented here only as a tentative hypothesis.

50. 1 ARMINJON-NOLDE-WOLFF, op. cit. supra note $23, \S 363$.

51 See note 6 supra.

52. Cf. Patton, Future of Trust Legislation in Latin America, 20 Tulane L. REv. 542, 544 (1946).

53. The most usual is the division in the naked (mue) ownership and the usufruct. Compare the limitations on an heir with substitution ("trustee" with a temporary usufruct) specified in Cour de cassation (Ch. civ.), Feb. 28, 1923, [1925] D. I. 189. Another interesting practice is antichrèse (" $\mathrm{a}$ contract by which a debtor transfers to his creditor the property rights to his immovables, for him to receive the use or the proceeds therefrom up to the total of the debt," 2 Planiol, op. cit. supra note 20 , at 766), which establishes a quasi-trust relationship between the debtor and the creditor who, although legal owner, is only such pro tempore and under obligation to surrender the ownership when the debt has been paid. Although not frequent, antichrèse has been put to uses which remind some of the trust practices. For instance, debtors of non-hypothecated real properties have simulated debts with their friends and constituted an antichrèse, thus preserving, al- 
lation to bring about the dédoublement de la propriété, ${ }^{54}$ which involves the raising of the beneficiary's claim to a right in rem rather than merely a personal obligation of the intermediary-trustee. Herein lies the ultimate difference between the civil and common-law status of trusts or trust-like relations-a gap which the French courts were able to span functionally, as the case of foundations illustrated, but of which the "legitimate" substantive law has not yet taken notice.

\section{IV}

The analysis of the French fondations and the corollaries developed in the preceding pages also suggest a few facts and relationships which (1) illustrate the difficulty of drawing clear lines-as the tendency has often been-between common and civil law, (2) caution against too easy formulae explaining the shapes and trends of the two legal systems, and (3) support the assumption that the analysis of differences could be made more simple and effective by choosing the proper functional, rather than formal, focus in each case.

The trust practice grew in England as a direct corollary of feudal seisin but developed its ultimate potentialities in America, a country without feudal history but with a conducive economy. France's culture was historically conditioned by rigid feudalism with exactly the same distinction between legal and equitable ownership ${ }^{55}$ as prevailed in England; these feudal concepts were uprooted by the French Revolution in the name of individualism and liberty, with a strong economic undertone, but they returned through the judicial back door, different in form but aspiring at a similar function.

A similar inconsistency, which makes a black-and-white interpretation of the two systems so questionable is at hand in a closely related situation. The same revolutionary and individualistic ideology of Code Napoléon, which has emancipated the individual owner of any but

though financially ruined, a means of living off the rent, and frustrating their real creditors who were usually unable to prove the fraud. Id. at 770 , quoting a doctoral thesis by Lobut (Paris 1897). Although exotic and rare, this practice illustrates the point that civil law is not impregnable to trust because of the insuperable barrier of divided or dual ownership. Compare also the prête-nom ("lend-name") convention which acts to conceal the identity of the mandant (principal), who, however, has the same action against the prête-nom as if he were an agent. Prête-nom is limited only by the requirement that it not cover illicit actions. Id. at 707-08.

Nor is it totally alien to the contemporary Continental mind, which has been psychologically prepared for the underlying conceptual pattern of the Anglo-American trust through the acquaintance with the idea of the holding company-the formal owner or instrument of control of the actual owner. Indeed the ideological or political attitude to this split ownership practice, which has all kinds of economicpolitical connotations, is often one of resistance or at least resentment.

54. "Le 'dédoublement de la propriété' est la pierre angulaire du trust." Mankiewicz, La fiducie québecoise et le trust de Common Laze, 12 RÉv. DE BARReAU 16, 19 (Canada 1952).

55. See note 16 supra. 
general legal restrictions on his property rights, imposed on him the légitime, the "will against the will," while Britain and United States, both less individualistic in the socio-psychological sense than France, have enjoyed full liberty of testation. ${ }^{.6}$

To proceed just one step farther: it has been suggested that the concept of indivisible property, the primary reason advanced for the non-existence of trusts in the civil law, has in it germs of economic collectivism and, perhaps, authoritarianism..$^{57}$ But England, supposedly impregnated with the conception of legal-economic individualism, ${ }^{58}$ has nationalized and socialized just as France and Germany. The latter sustained a genuine totalitarian régime, while France never did, although Section 903 of the Bürgerliches Gesetzbuch and Article 544 of the Code Civil, both keynoting the conception of indivisible property, are identical in essence.

These few examples illustrate the kind and size of cliches with which understanding of different legal systems has been burdened. Dispatching these old concepts to the museum of legal antiques and their replacement with more urbane "law in action" analysis is the largely uncompleted task of comparative legal study and research.

56. Cf., e.g., Nussbaum, Liberty of Testation, 23 A.B.A.J. 183 (1937), who quotes Max Weber on the relationship between economic dynamism of a society and the full freedom of testamentary disposition.

57. Bolgár, supra note 5.

58. Nussbaum, supra note 2, at 420, distinguishes the Continent from England and the "individualistic" trust area as inclined "toward socialism, be it of the bolshevik, the fascist, or the democratic type." Besides a slight eyebrow lift a political scientist will experience seeing the three types of socialism and "socialism" so simply juxtaposed, one may be allowed to suggest, with all respect due to Professor Nussbaum, that this particular line of division or counter-distinction between legal-economic individualism and socialization seems to be drawn in that somewhat light-handed and simplified manner which has characterized so much of the comparative analysis of common and civil law. 